\title{
Martin Amis, Neo-Orientalism, and Hubris
}

\begin{abstract}
A series of terrorist attacks in France and the UK during 2015-17 has brought to public attention many of the same issues raised in the wake of the 9/11 attacks in the US in 2001. In the process, long-running debates around the topic of the West's relationship to Islam have been given new impetus and numerous groups have reported an increase in anti-Islamic sentiment throughout Western Europe. In this fraught social and political context, the complex history of the West's interactions with Islam has tended to be displaced by a simplistic, neo-Orientalist narrative of a 'clash of civilisations'. This article focuses on Martin Amis's book "The Second Plane” as both a vivid early illustration of this tendency and as symptomatic of the various local, national, and geopolitical divisions which the myth of clashing civilisations serves to reinforce. Drawing on both William Connolly's work on tragedy and Edward Said's work on Orientalism, this article argues that what the example of Amis and 9/11 illustrates is the need for a sense of history in the debate over Islamism today.
\end{abstract}

Keywords: Amis, Said, Islamism, Orientalism, Civilisation, Tragedy, Terrorism, 9/11

\section{Introduction}

In the wake of the two terrorist attacks in France in 2015 - the first on the offices of the weekly satirical magazine Charlie Hebdo, the second on the Bataclan theatre - and the three terrorist attacks in Britain in 2017 - the first on the Palace of Westminster, the second on the Manchester Arena, and the third on London Bridge - many of the same issues raised by the attacks on New York City and Washington, D.C. in the US on $11^{\text {th }}$ September, 2001 have once again taken centre stage in the western media. Since the attacks of 2015-17, the question of the place of Islam within liberal-democratic societies has been a frequent discussion topic in newspapers, journals, television news programmes, and online. The attacks have intensified and given new impetus to long-running debates over such issues as radicalisation, blasphemy, religious freedom, censorship, immigration, surveillance, and western foreign policy. Fundamental questions have been raised in the public sphere about the nature, scope, and limits of democratic principles and liberal values. In these and other ways, Islamist violence has given rise to an anxious selfawareness on the part of the societies it has targeted.

Within ten days of the raid on the Charlie Hebdo offices, Tell MAMA, a group which tracks anti-Muslim violence, had recorded fifty-one separate instances of attacks on Muslims in France. ${ }^{1}$ During the following two months, the organisation collated evidence of widespread and often acute anti-Muslim sentiment in Britain, with Islamophobic graffiti, abuse of Muslims in public places, vandalism of mosques, and a high incidence of anti-Muslim hate speech reported in numerous British towns and cities. ${ }^{2}$ Similar trends were reported in Britain following the London and Manchester attacks. ${ }^{3}$ In the words of one commentator, the "rise of Isis...has been a disaster for the public image of Islam - and a boon for the Islamophobia industry." 4 As the findings of Tell MAMA show, Islamophobia presents a real and immediate threat to the lives and livelihoods of Muslim citizens throughout the west - a threat which Islamist incursions across the globe continue to exacerbate. ${ }^{5}$

With anti-Muslim sentiment on the rise throughout the west, it has become a matter of some urgency for all parties concerned to try to make fuller sense of the circumstances which have led to the present divisions and tensions. ${ }^{6}$ One thing that this will surely require is a careful reconsideration of recent (and not so recent) political history. Hanging over all of the debates being conducted today about the threat of Islamism is the long shadow cast by $9 / 11$. Since 2001, 9/11 has served as a paradigm or focal point for commentators on the phenomenon of Islamist terrorism. ${ }^{7}$ More specifically, it is in terms of the events of that day, and of the coordinates provided by the so-called War on Terror which followed immediately in its wake, that Islamist terrorism has tended to be understood in the western media. ${ }^{8}$ Consequently, if we wish to understand the role played by Islamism in contemporary discourse, we will first need to uncover and think through the origins of that discourse in the chaotic aftermath of the $9 / 11$ attacks. We 
will also need to consider the extent to which such discourse bears the imprint of historical influences and patterns which predate $9 / 11$ by decades and in some cases even centuries.

One high-profile contribution to the debates around Islamism which might be cited in this connection is the 2008 book The Second Plane by the British novelist Martin Amis. The volume of works published on Islamism, both prior to 2008 and since then, is, of course, very large indeed. Where Amis's book is particularly informative, however, is in the way it brings together and distils some of the west's chief post-9/11 preoccupations regarding its relationship to Islamism, Islam, and the middle east. As such, it functions as a point of intersection at which a number of historically significant cultural, political, and ideological tendencies converge. Looking back at The Second Plane from a distance of several years, and reconsidering it in light of subsequent events, it is possible to detect in Amis's book warning signs of how western attitudes towards both Islamism and Islam would develop in the period following its publication. Chief among these warning signs are the hubristic cast of much of Amis's rhetoric and, closely bound up with this, the Orientalist affinities of many of his arguments. It is with this neoOrientalist hubris - its nature, its historical origins, its aesthetic form, its political implications, and its relevance to our present moment - that we shall here be concerned.

\section{Connolly on Hubris}

In a series of recent studies, the political theorist William Connolly has made a case for viewing contemporary politics in terms of a theoretical paradigm inspired partly by the works of the Greek tragedian Sophocles. On Connolly's reading of Sophocles, the central human predicament involves negotiating a world that is "neither providential nor susceptible to consummate mastery." To this extent, Connolly is in broad agreement with the received view of many classicists. What makes Connolly's approach to Sophocles distinctive, however, is his redescription of Sophoclean tragedy in terms of twenty-first-century science. Drawing on research in the field of complexity theory, Connolly considers how various seemingly unrelated local factors can come together to produce global 'resonance machines' of vast destructive power. A resonance machine is any system in which the effects of certain elements serve to intensify the effects of other elements, leading, once certain threshold conditions have been reached, to the further intensification of the effects of the original elements and hence to the selfperpetuation of the entire process. Resonance machines typically exhibit what in the literature is known as the property of emergence: the phenomenon whereby dynamic, self-organising systems arise out of the interactions among components which do not themselves exhibit such properties. Complex systems, that is, are productive of patterns or behaviours which exert a causal influence on the parts of which they are comprised and are therefore irreducible to an inventory of those parts. They are, in other words, sui generis in the sense that they represent a genuine and quite unpredictable addition to the total stock of reality.

Hubris, on Connolly's definition, is the refusal to acknowledge the severe limitations which complex systems place on human cognition and agency. State actions, economic policies, social attitudes, political decisions, and consumption patterns, for example, can all be infused with hubris to the extent that they imply a denial of the extent to which they depend on factors, draw on influences, and give rise to effects which necessarily extend far beyond the awareness of those who initiate them. In a further novel updating of Greek tragedy, Connolly nominates for the role of the gods all those natural, social, political, technological, and economic forces whose interactions result in the emergence of global resonance machines. As Connolly observes, "a world marked by multiple gods who do not place human welfare high on their list bears an uncanny resemblance to a world of becoming composed of multiple, open force-fields..." 10 In a context of increasing global interconnection, marked financial instability, accelerating climate change, and the periodic collapse of political regimes throughout the world, Connolly advises us to attend to the counsel of seers like Tiresias: "a seer sees how crucial shifts in the pace of events and the timing of responses are to the world, while heroes and rulers invested with the hubris of 
consummate agency often fail to appreciate how they can become pawns of time, particularly when they lose sight of its shifting speeds and awesome power."11 Given, then, the allure of hubris as a means of denying the radical unpredictability, complexity, and vulnerability of the human situation, Connolly is led to commend an ethos of tragic humility, incorporating what he calls "a cultivated sensitivity to diverse events, human powers, and foibles." 12

Turning from theory to practical politics, Connolly draws a suggestive parallel between the warning Tiresias offers Creon in Antigone and the attempts by numerous figures to dissuade George W. Bush and Tony Blair from invading Iraq in 2003. ${ }^{13}$ Though the modern world would doubtless be alien to Sophocles in many respects, the hubristic cast of the War on Terror would likely have struck him as familiar. In Connolly's terms, what we have been witnessing since 9/11 is "hubris, resentments, tensions, and injustices accumulated from multiple sources condense into a global resonance machine of revenge and counter-revenge." ${ }^{14}$ Extending this line of thought, we might equally observe how more recent events have likewise followed a tragic trajectory fuelled by the pronounced hubristic tendencies of multiple parties. With the rise of Isis in Iraq and Syria and the spread of Islamophobia in Europe and the United States, the hubris inflecting western responses to Islamism can be seen to have produced precisely the kinds of tragic outcomes envisioned by Sophocles. Of course, such hubris is itself not without a complex history and pattern of development, part of which is vividly preserved in the textual strata of Martin Amis's The Second Plane.

\section{The Second Plane}

The Second Plane is a collection of essays and short stories about 9/11, Islamism, and a range of related issues originally written over a six-year period from 2001 to 2007 . One of the central contentions of the book is that the events of 9/11 represent a profound challenge to the literary imagination: "After a couple of hours at their desks, on September $12^{\text {th }}, 2001$, all the writers on earth were considering the course that Lenin menacingly urged on Maxim Gorky: a change of occupation." 15 According to Amis, 9/11 inaugurated "a distinct phase in history", one that "has given to us a planet we barely recognise" (p. 21). This view is not unique to Amis among contemporary British writers. In Ian McEwan's first published essay on 9/11, 'Beyond Belief', he contends that "the best or darkest dreamers of disaster on a gigantic scale, from Tolstoy and Wells to Don DeLillo, could not have delivered us into the nightmare available on television news channels yesterday afternoon." 16 The ominous, conspiracy-ridden fiction of DeLillo has proven to be a recurrent reference point among writers on 9/11. Amis remarks: "The temperature of planetary fear has been lifted towards the feverish; 'the world hum,' in Don DeLillo's phrase, is now as audible as tinnitus" (p. 7). It is notable that in this passage Amis portrays the fear instilled by $9 / 11$ in "planetary" rather than more local terms: 9/11, The Second Plane contends, was an event on a world-historical scale, a gateway to a new and enormously dangerous epoch.

Amis's earliest account of 9/11 - originally published on September $18^{\text {th }}, 2001$ - opens with the line: "It was the advent of the second plane, sharking in low over the Statue of Liberty: that was the defining moment" (p. 3). A range of associations accompany the word "sharking" in this sentence, whereby the image of a passenger plane is transformed into something sinister and predatory. The word is in part an allusion to the opening sentence of Amis's classic 1984 novel Money: "As my cab pulled off FDR Drive, somewhere in the early Hundreds, a low-slung Tomahawk full of black guys came sharking out of lane and sloped in fast right across our bows." 17 In the novel, the cab driver banks to avoid the oncoming vehicle and hits a pothole, causing the hung-over protagonist to hit his head sharply against the roof of the car, thereby foreshadowing the painful events which are to follow. On one level, this allusion serves to establish a continuity of affect between the two texts: the sinister imagery and undertone of the novel is redeployed in the essay. On a second level, Amis is trading implicitly on the cultural prestige attached to what is perhaps his best-known work: Money in a sense grants Amis the authority to speak of shark-like things. 
On yet a further level, however, the repetition of the shark trope may be seen as symptomatic of Amis's overall approach to 9/11. Throughout The Second Plane, Amis is generally less concerned with analysing the 9/11 attacks than with evoking the visceral experience of witnessing them. One consequence of this is that consideration of the historical context of the events is sidelined in the course of attempting to find a fitting aesthetic response to them. Especially in the earliest of the essays, it is as if, for Amis, 9/11 were first and foremost a challenge to the aesthetic imagination and only latterly, almost as an afterthought, an event with a history. When, however, in later essays, Amis turns to consider this history, he retains his impressionistic, aestheticising approach to the intricate social, political, and cultural realities which lay behind the attacks. Such an approach implicitly precludes the raising of certain kinds of question, producing a form of ideological blindness which serves to reinforce dominant perceptions of $9 / 11$ and the War on Terror, perpetuate existing antagonisms, and help sustain a vengeful global resonance machine. It also predetermines, in advance of the necessary evidence, the roles which Islamism, Islam, and the middle east will play in the narrative Amis constructs about the post-9/11 world.

One of the striking features of Amis's prose style - in both his fiction and non-fiction is the prevalence of neologisms. The impact of the second plane, for example, is described as a "worldflash" - the sudden dawning of a new age (p. 3). Islamists do not engage in suicide terrorism but in "self-bespatterment" - an unprecedented form of violence meriting its own grisly title (p. 71). Suicide terrorism itself is no longer merely terrorism but "horrorism" - something which exceeds more quotidian forms of terror (p. 71). Many more such constructions appear throughout the book. One implication of this linguistic inventiveness would appear to be that conventional language does not have the resources to describe either $9 / 11$ or the world it has given rise to. Alternatively, it can be viewed, once again, in the context of Amis's earlier writings.

Shortly before 9/11, Amis had published another collection of essays entitled The War Against Cliché. In that book, Amis cites the collection's title as a kind of mission statement for his work as an imaginative writer. His aim, he says, both as a novelist and as an essayist, has been to overcome stale linguistic formulations and refresh perceptions through the use of words in creative new ways: "To idealise: all writing is a campaign against cliché. Not just clichés of the pen but clichés of the mind and clichés of the heart." 18 This suggestive remark returns us to the question raised previously about Amis's view of the relationship of 9/11 to literature. Does Amis see the events of that day primarily as a challenge to his own (and others') aesthetic ingenuity, and only derivatively as a geopolitical event with a documentable history? One reason for answering this question in the affirmative is provided by Amis's short story 'The Last Days of Muhammad Atta'.

'The Last Days of Muhammad Atta' was originally published in 2006 and later reprinted unaltered in The Second Plane. In the story, Amis considers the motives of the 9/11 hijackers in exclusively personal, as opposed to political, terms. Atta, the hijacker pilot of American Airlines Flight 11, which crashed into the North Tower of the World Trade Centre, is said to act out of a rancorous, undiscriminating "detestation of everything" (p. 97), a "nihilistic insouciance" (p. 107) arising from a mixture of sexual and emotional frustration. Atta's righteous certainty is likewise interpreted by Amis as a sublimation of unspent sexual energy: "A very different kind of thirty-three-year-old might have felt the same tranced surety while contemplating an afternoon in a borrowed apartment with his true love (and sexual obsession)" (p. 100). Elsewhere, in the book's preface, Amis remarks that, "Geopolitics may not be my natural subject, but masculinity is. And have we ever seen the male idea in such outrageous garb as the robes, combat fatigues, suits and ties, jeans, tracksuits, and medics' smocks of the Islamic radical?" (p. x). In this passage Amis acknowledges at the outset of the book that The Second Plane is as much a continuation of his previous concerns - a perceived crisis in western masculinity, for example - as it is an account of recent history. ${ }^{19}$ As we have seen, Amis is content to extend techniques, imagery, and associations employed in his fiction to cover real world events. Relevant here is an essay from 2002 entitled 'The Voice of the Lonely Crowd', in 
which Amis's analysis takes a surprising detour through the history of twentieth-century literary criticism, making reference along the way to the work of F. R. Leavis, I. A Richards, William Empson, and Northrop Frye. Amis voices reservations about each of these figures, but commends them collectively for having championed culture and the virtues of the intellect against what he calls the "massive agglutination of stock response, of clichés, of inherited and unexamined formulations" (p. 19) characteristic of both ideological and religious thinking. Amis makes it clear that he conceives of his writings on $9 / 11$ as a contribution to this anti-dogmatic critical tradition with its ethos of irony and intellectual humility. As we shall see, however, Amis's endorsement of this tradition and wish to preserve its legacy do not in the end prevent him from trading in "inherited and unexamined formulations", often of a deeply ideological kind.

\section{Islam or Islamism?}

The Second Plane generally attributes Islamist terrorism to what Amis describes as a 'medieval' mindset. In addition to a fixation on insults and squabbles long since forgotten in the west, Amis sees irrationality and cultural underdevelopment as being among the root causes of the actions of groups like Al Qaeda. On Amis's account,

socialism was a modernist, indeed a futurist, experiment, whereas militant fundamentalism is convulsed in a late-medieval phase of its evolution. We would have to sit through a Renaissance and a Reformation, and then await an Enlightenment [before the fundamentalist threat abated]. And we're not going to do that (p. 9).

In this passage, Islamism is held to be a specifically medieval ideology - the result of a lack of intellectual progress on the European model. It is interesting to speculate here on whether Amis would be prepared to extend this view to other terrorist groups. Would he also see the actions of the I.R.A. - or, indeed, of any number of radical political factions - as equally 'medieval', the result of backwardness, ignorance, and underdevelopment? 9/11, Amis remarks at one point, was "a veritable Walpurgis night of the irrational" (p. 13) - one implication of this being that when Islamists commit terrorist acts it is as a result of their foregoing of rationality, whereas when other groups employ terror tactics these constitute an intelligible, albeit horrifying, form of political protest.

It is worth noting that, despite his passing reference to "militant fundamentalism" in the passage above, when Amis writes of the shortcomings of those who have failed to pass through a Renaissance or an Enlightenment, it is hard to resist the suspicion that he must be addressing Islam itself as opposed to Islamist ideology; it would seem to make little sense, after all, to isolate Al Qaeda in this respect and claim that it alone had bypassed these cultural periods. ${ }^{20}$ This suspicion is confirmed by further remarks by Amis. "All over again", he writes, "the West confronts an irrationalist, agonistic, theocratic/ideocratic system which is essentially and unappeasably opposed to its existence" (p. 9). In this passage Amis essentialises the west's enemies by uniting them under a single description; he identifies the non-western with the irrational; he moves from talking about terrorist cells to talking about middle eastern governments; he implies that terrorism is a coherent system, rather than a loose umbrella term for a host of disparate political agendas; and he implicates the world in a conflict whose only resolution lies in military action. Turning his gaze eastwards, Amis sees "a landscape of ferocious anachronisms" dominated by "the medieval agonism of Islam", itself an outgrowth of "the Bronze Age blunderings of the Middle East" (p. 13). The literary flair of these phrases drawn from one of Amis's later essays on 9/11 - ought not to distract us from their import. Whereas previously Amis had attributed Islamist terrorism to a medieval mindset, it now becomes the product of a far more ancient Bronze Age mentality: the "conflicts we now face or fear involve opposed geographical arenas, [and] also opposed centuries or even millennia" (p. $13)$. 
At this point, some pertinent remarks by the historian Eric Hobsbawm help to supply part of the wider context absent from Amis's polemic. Hobsbawm has criticised the view that the conflicts which have beset parts of the middle east since World War Two have primarily been the result of 'Islamic' values. The Syrian Ba'ath party, he notes, was "founded in the 1940s by two Paris-educated schoolteachers who...were ideologically anti-imperialist and socialist. ${ }^{21}$ Until the Gulf War, Iraqi politics was determined by nationalists, communists, and Ba'athists "all devoted to Arab unity and socialism (at least in principle), but distinctly not to the Law of the Qu'ran."22 The Algerian revolution, meanwhile, despite containing "a strong Islamic element", was understood by the revolutionaries themselves as "a struggle to destroy an anachronistic colonisation..." 23 Amis consistently overlooks this wider political and colonial context. The motives for suicide terrorism, he tells us, originate in "such old, old stuff" (p. 13) - a reference to religious grievances running back to the era of the Prophet Muhammad and ultimately back beyond that to the origins of monotheism itself. Reading Amis, one could at times be forgiven for thinking that suicide terrorism were a uniquely middle eastern problem, one with an essential link to the peoples of the region. Indeed, this view of suicide terrorism has been widespread in Europe and the United States since at least the 1960s. ${ }^{24}$ It is, however, as many commentators have shown, "not a pathology that afflicts any particular culture nor has it any close connections with religion." 25

In a similar vein to the writer Christopher Hitchens - another outspoken critic of both Islamism and Islam - Amis depicts the post-9/11 world as one in which religion and secularism are locked in mortal combat with one another. One of the points Amis repeatedly makes about Islamist terrorism is that it is essentially religious in nature. For Amis, Islamism is irrational because it is the product of the Islamic faith, which he defines, along with all other religions, as a form of primitive backwardness: "To be clear", he states, "an ideology is a belief system with an inadequate basis in reality; a religion is a belief system with no basis in reality whatever. Religious belief is without reason and without dignity, and its record is near-universally dreadful" (p. 14). There is an implied hierarchy in this passage between crimes committed in the name of ideology and those committed in the name of religion. Whilst ideologies such as Stalinism may have "an inadequate basis in reality", Islamism, as a supposed embodiment of the Islamic faith, has "no basis in reality whatever" and is therefore, Amis intimates, the more lethal of the two.

What these and many other similar passages make clear is that The Second Plane is underpinned by an Enlightenment-inspired developmental narrative of the kind excoriated by the early Frankfurt School thinkers, for whom it was far from obvious that modern European societies were less disposed to violence than their premodern counterparts. Amis follows in this respect New Atheist thinkers such as the evolutionary biologist Richard Dawkins and the philosopher A. C. Grayling in linking the irrationality of Islamism to what he sees as the obsolescence of organised religion in the modern world. ${ }^{26}$ "September $11^{\text {th" }}$, as he puts it in one essay, "was a day of de-Enlightenment" (p. 13). Such remarks suggest that Amis has not considered Theodor Adorno and Max Horkheimer's sobering observation, made in their Dialectic of Enlightenment, that "Enlightenment, in the widest sense of progressive thought, has always aimed at liberating men from fear and installing them as masters. Yet the fully enlightened earth is radiant with disaster triumphant." ${ }^{27}$ There is never a sense in The Second Plane of what Adorno and Horkheimer see as the ambiguity and potential for misuse inherent in all cultural achievements - up to and including Enlightenment rationality itself. Paradoxically, for all its concern with the tragedy of $9 / 11$, it may be that there is in fact too little sense of the tragic in The Second Plane.

\section{A Clash of Civilisations?}

Amis's claim, considered above, that the "conflicts we now face or fear involve opposed geographical arenas, [and] also opposed centuries or even millennia" is worth revisiting. In his 
influential book The Clash of Civilisations and the Remaking of World Order, the political theorist Samuel Huntington advances a dramatic thesis about international relations. Since its initial appearance, this thesis has helped to bring about a paradigm shift in thinking about state security and geopolitics, and has had a decisive influence on American foreign policy, as well as framing much western political discourse since the $1990 \mathrm{~s} .{ }^{28}$ Drawing partly on the work of an earlier generation of scholars, including the historian Arnold Toynbee, author of an ambitious, multi-volume 'universal history', Huntington argues that humanity is divided into a number of discreet units which he, following Toynbee, calls 'civilisations'. The cultural values of each of these self-contained civilisations are incommensurable with one another: 'Orthodox' or Eastern European civilisation is said to be incompatible with the 'Muslim' civilisation of the Greater Middle East, for instance. According to Huntington, it is conflicts between entire civilisations which determine the course of world history. From this perspective, the period through which we are currently living is, Huntington claims, unique: in "the post-Cold War world, for the first time in history, global politics has become multipolar and multicivilisational" (emphasis in original). ${ }^{29}$ According to Huntington, our globalised world is in a highly unstable condition because it is both polarised between a number of powerful nation-states and divided between a variety of incompatible civilisations.

In an obvious allusion to Huntington, Amis in one essay quotes approvingly the philosopher Sam Harris's characterisation of the years following 9/11 as the time "when civilisations come clashing" (p. 74). Though Huntington is nowhere acknowledged by name, The Second Plane draws heavily on his central thesis. ${ }^{30}$ This intellectual derivation helps both to explain the book's essentialising of immensely complex entities such as Islam or the western intellectual tradition and to account for the uncompromising, hubristic quality of many of its arguments and assertions. The Second Plane holds Islamism to be the most severe present-day threat to western societies and to world security more generally. Although he discusses the careers of specific Islamists in some detail, there is, paradoxically, rarely a sense in Amis's writing that Islamism is comprised of disparate individuals and groups involved in different conflicts and working towards different, and sometimes contradictory, objectives. Instead, The Second Plane gives the impression of a singular, unified Islamist ideology which found its purest expression in the 9/11 attacks. By contrast, William Connolly notes that since 9/11 there have been "significant clashes within both Islamic and Euro-American regions, with some factions in each contributing passion to a machine destructive of both." ${ }^{31}$ One thing Connolly's observation draws our attention to is the need for sustained reflection on the porosity of so-called civilisational boundaries and the fine-grained, contradictory interplay of factors which fables of monumental zero-sum power struggles too easily ignore. In the course of his polemic, Amis sometimes slips from talking about the nineteen hijackers of $9 / 11$, to talking about Islamism, to talking about Islam, and finally to talking about the 'East'. There are two clear consequences which follow from this tendency to imply that the perpetrators of the $9 / 11$ attacks were the envoys of an opposing civilisation. The first is that an entire civilisation - the 'Islamic' bloc of Huntington's analysis - is defined as implacably hostile to the west and its values. The second is that all engagements between these two civilisations must subsequently be understood in military terms. Once we grant the premise that the agents behind 9/11 - or London or Paris - embody the will of a vast quadrant of the world, Huntington's clash of civilisations appears virtually inevitable. ${ }^{32}$ The assurance with which Amis grants this premise is itself, of course, not without its hubristic implications.

As Connolly has observed, Huntington may be thought of as "a warrior on one side of the machine" - that is, as representing certain bellicose political tendencies deeply entangled with and partially defined by a host of countervailing forces, including, at times, the very forces they oppose. ${ }^{33}$ The hubris implied by this ethico-political orientation - whereby an excessive confidence in one's ability to discriminate 'friend' from 'foe' is combined with a readiness to decide questions of colossal cultural and historical import in the blink of an eye - recalls the catastrophic one-sidedness of Creon and the grief to which it brought him and his family. In framing his treatment of Islamism in terms of a Huntingtonian clash of civilisations, Amis spurns 
the thoughtful circumspection of Tiresias and sanctions a drastic oversimplification of both contemporary and historical reality.

\section{Neo-Orientalism}

In adopting the view of world history, east-west relations, Islam, western reason, and contemporary geopolitics outlined above, Amis can be seen to contribute to a long-standing tradition of Orientalist writing about the middle east in general and Arab societies in particular. The best known scholar and critic of Orientalist discourse is, of course, Edward Said. According to Said, the Orientalist,

approaches a heterogonous, dynamic, and complex human reality from an uncritically essentialist standpoint; this suggests both an enduring Oriental reality and an opposing but no less enduring Western essence, which observes the Orient from afar and, so to speak, from above. This false position hides historical change. Even more important, from my standpoint, it hides the interests of the Orientalist (emphasis in original). ${ }^{34}$

Orientalism illuminates The Second Plane in at least two ways. ${ }^{35}$ One of the most forceful - and, at the time of publication, controversial - points made by Said in Orientalism is that culture and politics are mutually constitutive. It is not merely the case, for Said, that culture ought to be understood partly in political terms, but, in addition, that politics ought to be understood partly in cultural terms - that is, that politics can be shown to take place within an imaginative space opened up and maintained by culture. As Ziauddin Sardar puts it, "Novelists are no longer just novelists - they are also global pundits shaping our opinions on everything from art, life, and politics to civilisation as we know it." ${ }^{36}$ Upon its publication, The Second Plane attained a strong position on the New York Times Bestseller list; it received very positive reviews in many newspapers; and was later reissued in a second, paperback edition. Amis's book has, then, both informed, and made an important contribution to, public debate about Islamism. From a Saidian perspective, The Second Plane may be viewed as a notable instance of culture helping to accommodate and sustain a particular political outlook. In its rearticulation of a number of key Orientalist assumptions in a twenty-first-century context, this outlook may be characterised as neo-Orientalist.

A second way in which Orientalism relates to our present concerns lies in Said's contention that the Orientalist understanding of Islam is structurally prejudiced. As well as being prejudiced in many of its particulars, that is, the Orientalist paradigm is prejudiced in its fundamental orientation:

The earliest European scholars of Islam...were medieval polemicists writing to ward off the threat of Muslim hordes and apostasy. In one way or another that combination of fear and hostility has persisted to the present day, both in scholarly and non-scholarly attention to an Islam which is viewed as belonging to a part of the world - the Orient counterposed imaginatively, geographically, and historically against Europe and the West. $^{37}$

On the model of Foucault's Discipline and Punish, Said in Orientalism traces a genealogy of the European understanding of Islam. Like Foucault, Said is concerned to uncover how supposedly impartial claims to knowledge dissimulate the interests of those who advance them. Said shows how, more specifically, certain historical conditions in Europe - including the great imperial projects of the nineteenth century - gave rise to a negative stereotyping of Arabs, who came to be associated by Europeans with irrationality, fanaticism, and violence. The fact that elements of this stereotype, with its roots in the medieval Crusades, can be found at work in Amis's post-9/11 
writings provides an ironic counterpoint to his own polemical use of the term 'medieval' in reference to Islamist militants.

Although it does not address Orientalism or explicitly anticipate such a charge, The Second Plane does pre-empt a related objection which Amis attributes to a figure he calls the 'liberal relativist': "That's what all this was supposed to be: not a clash of civilisations or anything like that, but a civil war within Islam. Well, the civil war appears to be over. And Islamism won it" (p. 50). Beneath the sarcasm - "That's what all this was supposed to be" - and the rhetorical flourishes - "Well, the civil war appears to be over" - an enormous claim is being made by Amis in this passage. The upshot of the fourth, brief sentence - "And Islamism won it" - is that Islam as formerly understood has ceased to exist. Because of the somewhat oblique character of Amis's assertions his conclusion is not immediately obvious. But on reflection there seems to be only one point he could be making: that Islam, a world religion with a community of more than one-and-a-half billion people, has decided en masse to exchange its ideals of peace, compassion, and social justice for the murderous creed of Osama bin Laden and his followers. One of the topics addressed in Said's Orientalism is the European suspicion - once again, with roots in the medieval period - that east and west cannot peacefully coexist. It is unlikely that Amis would have arrived at his conclusion - the hasty and unsubstantiated view that the 'civil war' within Islam is over and that Islamism has triumphed - independently of the neo-Orientalist assumptions which, as we have seen, underlie much of his thinking in this area.

Another reason for Amis's dissatisfaction with the 'liberal relativist' stance has to do with what he calls the 'moral equivalence' argument. Since 9/11 there has been a perception, shared by many liberals, that certain longstanding political convictions of liberal societies - including religious toleration, equality before the law, multiculturalism, and the prohibition on torture have become open to question on pragmatic grounds. Writers such as Christopher Hitchens and Sam Harris, for instance, have argued that liberal societies must make certain 'realistic' concessions if they are to survive the onslaught of Islamism. It is the opponents of this view whom Amis labels 'liberal relativists' - the idea being that cultural and moral relativism have made some in the west hesitant to condemn illiberal Islamist traits, including anti-Semitism, misogyny, religious persecution, and the use of terroristic violence. Amis argues that this hesitation arises from the liberal relativist's fear of betraying her own ideals of tolerance, cosmopolitanism, and respect for difference: "No value can be allowed to stand in stone, so we begin to question our ability to identify even what is malum per se" (p. 74). One notable episode, which took place during an appearance by Amis on the BBC television programme Question Time, highlighted for him the main failing of the liberal relativist position. After pledging his support for the 2001 U.S.-led invasion of Afghanistan, Amis found that the studio audience were in strong disagreement with him. He comments:

This was not equivalence; this was hemispherical abjection. Accordingly, given the choice between George Bush and Osama bin Laden, the liberal relativist, it seems, is obliged to plump for the Saudi, thus becoming the appeaser of an armed doctrine with the following tenets: it is racist, misogynist, homophobic, totalitarian, inquisitional, imperialist, and genocidal (p. 200).

What is at issue here is the way Amis reduces the possible responses to 9/11 to two options: support for military intervention, or appeasement of Islamism. The implication is that to oppose the invasion is simply to be a relativist, prepared to tolerate Islamist violence on the grounds either that the west in some sense 'deserves' its tragedies, or that people of other cultures simply do things differently and so must be 'respected'. This is a form of sophistry. The false dichotomy underpinning Amis's thinking about Islamism functions to silence dissenting views by excluding all but two voices from the conversation: the interventionist or 'liberal hawk', and the hypothetical liberal relativist. 
Five years after his Question Time appearance, in 2006, Amis's uncompromising stance on Islamism once again drew media attention, prompting him to enter into a debate with the literary critic Terry Eagleton. One essay by Amis, entitled 'The Age of Horrorism' (later included in The Second Plane under the title 'Terror and Boredom: the Dependent Mind'), provoked Eagleton to rebuke Amis for equating Muslims with terrorists. ${ }^{38}$ Eagleton did so both at the time, in print, and again two years later in the wake of the publication of The Second Plane, in the preface to a new edition of his Literary Theory: An Introduction. ${ }^{39}$ Eagleton argued that it is incumbent upon opinion-forming intellectuals like Amis to oppose the discrimination and infringements of civil liberties which $9 / 11$ and the War on Terror have frequently been held to excuse. A handful of remarks by Amis on the British Muslim community in an interview given in August 2006 then became the centre of a larger debate conducted throughout the British media, during which Amis and Eagleton each made television appearances and authored numerous articles. ${ }^{40}$ The comments by Amis which initially provoked the controversy were as follows:

There's a definite urge - don't you have it? - to say, 'The Muslim community will have to suffer until it gets its house in order.' What sort of suffering? Not letting them travel. Deportation - further down the road. Curtailing of freedoms. Strip-searching people who look like they're from the Middle East or from Pakistan...Discriminatory stuff, until it hurts the whole community and they start getting tough with their children... ${ }^{41}$

A year later, at the Cheltenham Literature Festival, Amis revived the controversy when he remarked that Muslim states were less "civilised" than those of the west and went on to claim that, "Some societies are just more evolved than others." 42 Three years later again, however, in 2010, Amis backed down from this position and issued a semi-apology for his earlier comments on deportation and discrimination: "It was a rash remark made at a terrible time. Ten years on from September 2001, we have still not got a usable word for what we mean. People think you are talking about Islam but you are not." ${ }^{43}$

This latter statement brings to mind an important passage from The Second Plane, in which Amis writes: "Far from wanting or trying to exterminate it, the West had no views whatever about Islam per se before September 11 $11^{\text {th }}$ 2001" (p. 63). This is an astonishing sentence. It is astonishing because it implies a profound political blindness and historical insensitivity on the part of one of Britain's most celebrated writers and public intellectuals. Amis is suggesting that prior to 9/11 Islam was a neutral category for the west, one wholly lacking in historical and political significance. Whatever criticisms may have been voiced about Orientalism since its publication, one aspect of Said's work which is surely not in dispute is his contention that Islam and the west have had a long and extremely complex relationship. Perhaps if Amis had been more aware of this history - including some of its darker aspects - he would have been quicker to recognise the sorts of stereotypes, myths, and outright misrepresentations on which he was drawing. He may also have been more cautious in his judgements, slower to demonise and denounce, and less inclined to assume he had taken the measure of the circumstances which give rise to terrorism.

\section{Amis, Blair, Creon}

On Sunday $25^{\text {th }}$ October, 2015, Tony Blair gave an interview to $C N N$ in which the former British Prime Minister offered a qualified apology for a number of key failings in the planning and orchestration of the 2003 invasion of Iraq. Blair apologised for using misleading intelligence and failing to pre-empt and adequately prepare for the aftermath and longer-term outcomes of the war. ${ }^{44}$ When asked if he saw the war as the principal cause of the rise of Isis, Blair replied, "I think there are elements of truth in that." 45 In response to this interview, which became one of the most discussed items on the Internet over the following days, commentators were quick to note that Blair's apology signalled a remarkable, albeit qualified, reversal in his view of the conflict. 
Martin Chulov, the Guardian's middle east correspondent, provided an analysis of the process whereby, since 2003, a miscellaneous assortment of groups in Iraq animated by "a broad Sunni discontent fuelled by the invasion" evolved into "a serendipitous vanguard that not long afterwards organised into Al Qaida in Iraq, then the Islamic State of Iraq and, since mid-2013, Isis." 46 Chulov argues that the coalescence of Isis between 2003 and 2013 can be attributed to a range of factors flowing directly from western intervention: the toppling of a Sunni government, the installation of a rival Shia power, a perceived western pivot towards Iran and Persian hegemony, the damage done to the country's infrastructure, loss of jobs and unemployment, mass incarceration and the abuses of Abu Ghraib, and a host of other humiliations, both sanctioned and unsanctioned. ${ }^{47}$ As Chulov notes, Sunni jihadis regard the U.S.-run prison system as "their most effective organising tool", while Isis "openly hails 2003 as its raison d'etre."

Having supported the invasion of Afghanistan in 2001, Amis consistently opposed the invasion of Iraq. In an essay entitled 'The Wrong War', originally published in March 2003, the month of the invasion, and later included in The Second Plane, Amis subjects each of the main arguments for the war to incisive criticism. He draws particular attention to their logical inconsistencies and insubstantial evidential basis (pp. 23-25; 28-29). Amis specifies that for a war to be justified, "the belligerent nation must be more or less certain that its actions won't make things worse" (p. 28). In Amis's view, the inability of Tony Blair, George W. Bush, or anyone else to predict the outcomes of the conflict with any degree of certainty, combined with the potential for lethal repercussions throughout the world should the mission not go according to plan, rendered the invasion unjustifiable (p. 28). In saying this, Amis took on the role of a modern Tiresias by offering a prophetic warning about the delusiveness of rulers invested with what Connolly calls "the hubris of consummate agency." 49

When Tony Blair made the decision to invade Iraq he refused to listen to those who warned him of the venture's liability to create havoc in the region and to radicalise a new generation of Islamist fighters. When Martin Amis repeatedly conflated Islamism with Islam and employed the rhetoric of clashing civilisations he dismissed dissenting voices by branding his critics 'liberal relativists' and accusing them of complicity with terrorism. Confronted by the multiple atrocities committed by Isis since 2013, Blair now recognises that the invasion which he oversaw has had, and continues to have, deadly unforeseen consequences. Almost ten years after his entry into the debates around 9/11, and in light of the violent Islamophobia which has spread throughout the west in the intervening period, Amis has distanced himself from his more severe comments on Islam and acknowledged a crucial distinction between the Islamic faith and Islamist ideology. In the regrets voiced by both men an echo of Creon's rueful words at the end of Antigone can be heard:

\author{
Sometime back, a god struck \\ my head an immense blow, \\ it drove me \\ to act in brutal ways, \\ ways that stamped out \\ all my happiness. \\ What burdens and what pain \\ men suffer and endure..$^{50}$
}

One thing that Blair's decision on Iraq and Amis's writings on Islamism serve to illustrate is the ease with which hubris can come to infuse state action and public discourse at times of anxiety and distress. As a public intellectual, Amis had, and indeed still has, the opportunity to fulfil the role of Tiresias, as he momentarily did in 2001; in his confrontation with Islamism, however, he has for the most part preferred to ally himself with Creon. In light of the tragic legacy of the west's response to Islamist terrorism thus far, it seems clear that two things are called for above all in any future conversation on the subject. The first is an acknowledgement of the ways in 
which the challenges facing the world today resist reductive explanations and formulaic solutions. The second, as the case of The Second Plane amply demonstrates, is a much-needed sense of history. 


\section{REFERENCES}

Adorno, Theodor, and Max Horkheimer. Dialectic of Enlightenment. Translated by Edmund Jephcott. California: Stanford University Press, 2002.

Ali, Tariq. The Clash of Fundamentalisms: Crusades, Jihads, and Modernity. London: Verso, 2003.

Amis, Martin. Money. London: Penguin, 2000.

Amis, Martin. The Second Plane. London: Vintage, 2008.

Amis, Martin. The War Against Cliché. London, Vintage, 2001.

Chulov, Martin. "Tony Blair is Right: Without the Iraq War There Would Be No Islamic State", The Guardian, October 25, 2015. Accessed May 18, 2017.

http://www.theguardian.com/world/2015/oct/25/tony-blair-is-right-without-the-iraqwar-there-would-be-no-isis.

Connolly, William. A World of Becoming. London: Duke University Press, 2011.

Desai, Meghnad. Rethinking Islamism: The Ideology of the New Terror. London: I. B. Tauris, 2007.

Dibb, Mike. Edward Said: The Last Interview. UK: Drakes Avenue, 2004.

Donadio, Rachel. “Amis and Islam”. New York Times, March 9, 2008. Accessed May 19, 2017. http://www.nytimes.com/2008/03/09/books/review/Donadio-t.html.

Eagleton, Terry. The English Novel. Oxford: Blackwell, 2005.

Eagleton, Terry. Ideology: An Introduction, $2^{\text {nd }}$ edn. London: Verso, 2007.

Eagleton, Terry. Literary Theory: An Introduction, $3^{\text {rd }}$ edn. London: Blackwell, 2008.

Eagleton, Terry. "Rebuking Obnoxious Views is Not Just a Personality Kink". The Guardian, October, 10, 2007. Accessed May 21, 2017.

http://www.guardian.co.uk/commentisfree/2007/oct/10/comment.religion.

Gray, John. Black Mass: Apocalyptic Religion and the Death of Utopia. London: Penguin, 2007.

Gray, John. False Dawn: The Delusions of Global Capitalism. London: Granta, 1999.

Hasan, Mehdi. "How Islamic is Islamic State?". The New Statesman, March, 10, 2015. Accessed May 20, 2017. http://www.newstatesman.com/world-affairs/2015/03/mehdi-hasan-howislamic-islamic-state.

Hobsbawm, Eric. The Age of Extremes. London: Abacus, 2007.

Huntington, Samuel. The Clash of Civilisations and the Remaking of World Order, $2^{\text {nd }}$ edn. London: Simon \& Schuster, 2002.

Jones, Aidan. "Martin Amis No Stranger to Controversy". The Guardian, January, 24, 2010. Accessed May 22, 2017. http://www.theguardian.com/books/2010/jan/24/martin-amiseuthanasia-islam-controversy.

McEwan, Ian. "Beyond Belief”. The Guardian, September, 12, 2001. Accessed May 21, 2017. www.guardian.co.uk/world/2001/sep/12/september11.politicsphilosophyandsociety.

Mullen, Jethro. "Tony Blair Says He's Sorry for Iraq War 'mistakes', but Not for Ousting Saddam”. CNN, October, 25, 2015. Accessed May 20, 2017. http://edition.cnn.com/2015/10/25/europe/tony-blair-iraq-war/index.html.

Said, Edward. Covering Islam: How the Media and the Experts Determine How We See the Rest of the World. London: Vintage, 1997.

Said, Edward. Orientalism. London: Penguin, 2003.

Sardar, Ziauddin. "The Blitcon Supremacists". The Guardian, December, 9, 2006. Accessed May 21, 2017. www.theguardian.com/commentisfree/2006/dec/09/comment.bookscomment.

Scruton, Roger. The West and the Rest: Globalization and the Terrorist Threat. London: Continuum, 2003.

Sophocles. Antigone in The Complete Plays of Sophocles. Translated by Robert Bagg and James Scully. New York: HarperCollins, 2011.

Tell MAMA. "Angry Locals Remove Antisemitic, Anti-Muslim Posters in Scotland". July 27, 2017. Accessed July 28, 2017. https://tellmamauk.org/angry-locals-remove-antisemiticanti-muslim-posters-in-scotland. 
Tell MAMA. "51 Anti-Muslim Incidents in France”. January 17, 2015. Accessed May 20, 2017. http://tellmamauk.org/2015/01.

Tell MAMA. "Manchester Mosque Arson Being Treated as a Hate Crime". July 17, 2017. Accessed July 28, 2017. https://tellmamauk.org/manchester-mosque-arson-beingtreated-as-a-hate-crime.

Tell MAMA. "Monthly Archives: February and March". March, 26, 2015. Accessed May 20, 2017. http://tellmamauk.org/2015/02 and http://tellmamauk.org/2015/03.

Tell MAMA. "Who's Behind the Latest Threatening Hate Mail to Mosques?” July 6, 2017. Accessed July 28, 2017. https://tellmamauk.org/whos-behind-the-latest-threateninghate-mail-to-mosques.

\section{Notes}

${ }^{1}$ Tell MAMA, "51 Anti-Muslim Incidents in France”, January 17, 2015, accessed May 20, 2017, http://tellmamauk.org/2015/01.

2 Tell MAMA, "Monthly Archives: February and March", March, 26, 2015, accessed May 20, 2017, http://tellmamauk.org/2015/02 and http://tellmamauk.org/2015/03.

${ }^{3}$ Many such incidents could be cited here. For three illustrative examples from the month of July alone, see: Tell MAMA, "Who's Behind the Latest Threatening Hate Mail to Mosques?", July 6, 2017, accessed July 28, 2017, https://tellmamauk.org/whos-behind-the-latest-threatening-hatemail-to-mosques; Tell MAMA, "Manchester Mosque Arson Being Treated as a Hate Crime", July 17, 2017, accessed July 28, 2017, https://tellmamauk.org/manchester-mosque-arson-beingtreated-as-a-hate-crime; Tell MAMA, "Angry Locals Remove Antisemitic, Anti-Muslim Posters in Scotland", July 27, 2017, accessed July 28, 2017, https://tellmamauk.org/angry-locals-removeantisemitic-anti-muslim-posters-in-scotland.

${ }^{4}$ Mehdi Hasan, "How Islamic is Islamic State?", The New Statesman, March, 10, 2015, accessed May 20, 2017, http://www.newstatesman.com/world-affairs/2015/03/mehdi-hasan-how-islamicislamic-state.

${ }^{5}$ Time magazine's Foreign Editor Bryan Walsh attributes the growth of Islamophobia in Western Europe partly to a recent resurgence in nationalism. Walsh cited in Ben Goldberger, "The Brief: The Rise of Islamophobia in Western Europe", Time, January 8, 2015, accessed May 20, 2017, http://time.com/3660414/western-europe-rising-islamophobia-charlie-hebdo-paris.

${ }^{6}$ Donald Trump, for example, has been awarded the 'Islamophobe of the Year' Award by the Islamic Human Rights Organization (IHRC). Tara John, "Donald Trump Named Islamophobe of the Year by Muslim Group", Time, March 5, 2016, accessed May 20, 2017, http://time.com/4245957/donald-trump-islamophobia-award.

${ }^{7}$ For a highly insightful critique of this tendency, to which I am much indebted, see Meghnad Desai, Rethinking Islamism: The Ideology of the New Terror (London: I. B. Tauris, 2007).

${ }^{8}$ See Said's discussion of this issue in Mike Dibb's documentary, Edward Said: The Last Interview (UK: Drakes Avenue, 2004).

${ }^{9}$ William Connolly, A World of Becoming (London: Duke University Press, 2011), 98.

${ }^{10}$ Connolly, 155.

${ }^{11}$ Ibid., 153.

${ }^{12}$ Ibid., 153.

${ }^{13}$ Ibid., 155.

${ }^{14}$ Ibid., 138.

${ }^{15}$ Martin Amis, The Second Plane (London: Vintage, 2008), 11. All subsequent references in parentheses.

${ }^{16}$ Ian McEwan, “Beyond Belief”, The Guardian, September, 12, 2001, accessed May 21, 2017, http://www.guardian.co.uk/world/2001/sep/12/september11.politicsphilosophyandsociety. 
${ }^{17}$ Martin Amis, Money (London: Penguin, 2000), 1.

${ }^{18}$ Martin Amis, The War Against Cliché (London, Vintage, 2001), xv.

${ }^{19}$ Writing of Amis's fiction, Terry Eagleton has observed that, "brilliance of technique is qualified by a postmodern brittleness, one which makes his work seem as much a symptom of [late capitalist] culture as a critique of it." Eagleton, The English Novel (Oxford: Blackwell, 2005), 334.

${ }^{20}$ This is not to say that cultural and political reforms in certain Muslim-majority states are either impossible or undesirable. The Muslim scholar Tariq Ali has argued that Islam in the twenty-first century is in need of a reformation, calling for the "rigid separation of state and mosque; the dissolution of the clergy; the assertion by Muslim intellectuals of their right to interpret the texts that are the collective property of Islamic culture as a whole; the freedom to think freely and rationally and the freedom of imagination..." Ali quoted in Caroline Cox and John Marks, The 'West', Islam, and Islamism (London: Civitas, 2003), 74.

${ }^{21}$ Eric Hobsbawm, The Age of Extremes (London: Abacus, 2007), 174.

${ }^{22}$ Hobsbawm, Age of Extremes, 174.

${ }^{23}$ Ibid., 174.

${ }^{24}$ See Chapter One of Edward Said, Covering Islam: How the Media and the Experts Determine How We See the Rest of the World (London: Vintage, 1997).

${ }_{25}$ John Gray, Black Mass: Apocalyptic Religion and the Death of Utopia (London: Penguin, 2007), 175.

${ }^{26}$ Richard Dawkins's essay on 9/11, however, follows Amis in conflating Islam with Islamism. See Dawkins, "Religion's Misguided Missiles", The Guardian, September, 15, 2001, accessed May 21, 2017, www.guardian.co.uk/world/2001/sep/15/september11.politicsphilosophysociety.

27 Theodor Adorno and Max Horkheimer, Dialectic of Enlightenment, trans. Edmund Jephcott (California: Stanford University Press, 2002), 1.

${ }^{28}$ One possible explanation for the popularity of Huntington's thesis is the status it accords to America. John Gray has noted that Huntington's thesis is "incorrigibly Americocentric, purveying a view of the world that is unrecognisable to the majority of Asians or Europeans." Gray, False Dawn: The Delusions of Global Capitalism (London: Granta, 1999), 120.

${ }^{29}$ Samuel Huntington, The Clash of Civilisations and the Remaking of World Order, $2^{\text {nd }}$ edn. (London: Simon \& Schuster, 2002), 21.

${ }^{30}$ Other prominent examples of popular works which have drawn on this thesis in the wake of 9/11 include the philosopher Roger Scruton's The West and the Rest: Globalization and the Terrorist Threat (London: Continuum, 2003) and the historian Niall Ferguson's bestselling Civilization: The Six Killer Apps of Western Power (London: Penguin, 2011).

${ }^{31}$ Connolly, 139.

32 Again, the rhetoric of a clash of civilisations is not unique to Amis among British commentators: McEwan, for instance, argues that 9/11 brought to light the traumatic recognition that, "Our civilisation...is easy to wreck when there are sufficient resources and cruel intent." McEwan, "Beyond Belief".

${ }^{33}$ Connolly, 139.

${ }^{34}$ Edward Said, Orientalism (London: Penguin, 2003), 333-334.

${ }^{35}$ One reason it is perhaps unsurprising that Amis's approach to Islamism should be implicated in Orientalist thinking is that The Second Plane is informed - as Amis acknowledges at several points - by the work of the neoconservative Orientalist scholar Bernard Lewis, a figure singled out for severe criticism throughout Said's published works and one of his key opponents in debates over such issues as Israel-Palestine, pan-Arabism, the place of secularism in the middle east, the Gulf War, the 2003 invasion of Iraq, and the War on Terror.

${ }^{36}$ Ziauddin Sardar, "The Blitcon Supremacists", The Guardian, December, 9, 2006, accessed May 21 , 2017 ,

http://www.theguardian.com/commentisfree/2006/dec/09/comment.bookscomment.

${ }^{37}$ Said, 344. 
38 Terry Eagleton, "Rebuking Obnoxious Views is Not Just a Personality Kink", The Guardian, October, 10, 2007, accessed May 2017, http://www.guardian.co.uk/commentisfree/2007/oct/10/comment.religion.

${ }^{39}$ Terry Eagleton, 'Preface to the Anniversary Edition' in Literary Theory: An Introduction, $3^{\text {rd }}$ edn (London: Blackwell, 2008). Eagleton also mentions Amis's views on Islamism in the preface to the second edition of his book Ideology: An Introduction, $2^{\text {nd }}$ edn (London: Verso, 2007).

${ }^{40}$ Eagleton was not the only commentator to take issue with Amis's remarks. The novelist Ronan Bennett, among others, argued that Amis's views were "symptomatic of a much wider and deeper hostility to Islam and intolerance of otherness" in post-9/11 Britain. See Bennett, "Shame on Us", The Guardian, November, 19, 2007, accessed May 20, 2017, http://www.theguardian.com/uk/2007/nov/19/race.bookscomment.

${ }^{41}$ Amis quoted in Rachel Donadio, “Amis and Islam”, New York Times, March 9, 2008, accessed May 19, 2017, http://www.nytimes.com/2008/03/09/books/review/Donadio-t.html.

42 Amis quoted in Aidan Jones, "Martin Amis No Stranger to Controversy", The Guardian, January, 24, 2010, accessed May 2017, http://www.theguardian.com/books/2010/jan/24/martin-amis-euthanasia-islam-controversy.

43 Amis quoted in Tahira Yaqoob, "Martin Amis Comes Close to Apology Over Islam Comments", The National, March 12, 2010, accessed May 23, 2017,

http://www.thenational.ae/apps/pbcs.dll/article?AID=/20100313/NATIONAL/703129825/0/natio nal.

44 Tony Blair quoted in Jethro Mullen, “Tony Blair Says He's Sorry for Iraq War 'mistakes', but Not for Ousting Saddam", CNN, October, 25, 2015, accessed May 20, 2017, http://edition.cnn.com/2015/10/25/europe/tony-blair-iraq-war/index.html.

${ }^{45}$ Blair quoted in Mullen, “Tony Blair Says He's Sorry for Iraq War".

${ }^{46}$ Martin Chulov, "Tony Blair is Right: Without the Iraq War There Would Be No Islamic State", The Guardian, October 25, 2015, accessed May 18, 2017, http://www.theguardian.com/world/2015/oct/25/tony-blair-is-right-without-the-iraq-war-therewould-be-no-isis.

${ }^{47}$ Chulov, "Tony Blair is Right".

${ }^{48}$ Ibid.

${ }^{49}$ Connolly, 153.

${ }^{50}$ Sophocles, Antigone in The Complete Plays of Sophocles, trans. Robert Bagg and James Scully (New York: HarperCollins, 2011), 700. 